\title{
STRATEGI IMPLEMENTASI AKUNTANSI BASIS AKRUAL DI INSTITUT PERTANIAN BOGOR
}

\section{(Implementation strategy of accrual-based accounting in Bogor Agricultural University)}

\author{
Kusnadi $^{1}$, Hermanto Siregar ${ }^{2}$, Nirwan Ristiyanto ${ }^{2}$ \\ ${ }^{1}$ Staff Bagian Pajak, Biro Keuangan Institut Pertanian Bogor. Email: kusnadinaufal@gmail.com \\ ${ }^{2}$ Staff Pengajar Departemen Ilmu Ekonomi, Fakultas Ekonomi dan Manajemen, IPB. Email: \\ hermansiregar@yahoo.com \\ Staff Pengajar Pusat Pendidikan dan Pelatihan Pengawasan (Pusdiklatwas), Badan Pengawasan Keuangan dan \\ Pembangunan (BPKP) RI. Email: nirwanristiyanto@yahoo.com
}

\begin{abstract}
Accrual-based accounting is an accounting basis where economic transactions and other events are recognized, recorded and reported in the period of the transaction, not on cash or cash equivalent is received or paid. Accrual-based accounting better than cash-based accounting that recognizes transactions only when cash is received or paid. Implementation of accrual-based accounting at Bogor Agricultural University as an Autonomous public university with legal status intended for greater accountability, increased transparency and more informed decision-making. Factors that influence of implementation, namely, human resources, accounting system and organizational commitment. Likert scale used to determine the response of respondents to the third factor for subsequent analyzes using a rating scale analysis. Analytical Hierarchy Process (AHP) used to determine policy priorities that should be taken. The study concluded that development of the system is a top priority in implementing accrual-based accounting in Bogor Agricultural Universiy.
\end{abstract}

\section{ABSTRAK}

Akuntansi berbasis akrual adalah basis akuntansi di mana transaksi ekonomi dan peristiwa lainnya diakui, dicatat dan dilaporkan dalam periode transaksi berjalan, bukan pada kas atau setara diterima atau dibayarkan. Akuntansi basis akrual lebih baik dari akuntansi basis kas yang mengakui transaksi hanya ketika kas diterima atau dibayar. Pelaksanaan akuntansi berbasis akrual di Institut Pertanian Bogor sebagai Perguruan Tinggi Negeri badan hukum (PTN Badan Hukum) ditujukan untuk akuntabilitas yang lebih besar, peningkatan transparansi dan informasi yang lebih lengkap dalam pengambilan keputusan. Faktor-faktor yang mempengaruhi pelaksanaan akuntansi basis akrual yaitu, sumber daya manusia, sistem akuntansi dan komitmen organisasi. Skala Likert digunakan untuk menentukan tanggapan responden terhadap ketiga faktor tersebut. Analisis selanjutnya menggunakan analisis rating scale. Analytical Hierarchy Process (AHP) digunakan untuk menentukan prioritas kebijakan yang harus diambil. Studi ini menyimpulkan bahwa pengembangan sistem adalah prioritas utama dalam melaksanakan akuntansi berbasis akrual di Institut Pertanian Bogor.

\section{PENDAHULUAN}

Perubahan Manajemen sektor publik terjadi dalam beberapa dekade terakhir dengan penerapan New Public Management (NPM). NPM lahir sebagai suatu konsep pengelolaan sektor publik yang mengadopsi praktik manajemen sektor swasta yaitu menciptakan akuntabilitas yang berorientasi pada hasil (Upping dan Oliver 2011). Petre dan Cosmina (2009) menyatakan bahwa fokus dari NPM adalah efisiensi. Lahirnya konsep NPM merupakan reformasi bagi sektor publik untuk melakukan perbaikan dalam pengelolaan keuangan, manajemen dan organisasi.

Sektor publik merupakan salah satu sektor yang memiliki peran penting dalam suatu negara, sehingga dampak yang ditimbulkan atas kegagalan sektor publik akan berpengaruh kepada sektor lain. 
Mahmudi (2011) menyatakan bahwa kegagalan sektor publik dalam bentuk kegagalan pemerintah (government failure), kelumpuhan birokrasi, mafia hukum, kekacauan politik, perang, terorisme, korupsi, kolusi, dan nepotisme dapat mengganggu sektor bisnis dan sosial.

Perubahan akuntansi basis kas menjadi akuntansi basis akrual terhadap organisasi sektor publik di seluruh dunia menunjukkan adanya reformasi dalam manajemen keuangan sektor publik (Ofoegbu 2014). Tuntutan ini salah satunya berasal dari lembaga-lembaga internasional dan regional seperti International Monetary Fund (IMF), World Bank dan Asian Development Bank (ADB) sebagai lembaga pemberi pinjaman. Pelaksanaan akuntansi basis akrual untuk sektor pemerintah merupakan agenda yang harus dilaksanakan oleh negara peminjam agar bantuan yang diberikan dapat dipertanggungjawabkan dengan baik

Akuntansi basis kas merupakan basis akuntansi yang hanya mengakui penerimaan dan pengeluaran kas (Ofoegbu 2014). Kelebihan dari metode ini sangat sederhana, mudah untuk dipelajari dan adanya efisiensi sumber daya. Salah satu kelemahan dari metode ini adalah piutang dan utang tidak ditampilkan dalam neraca (Mahat dan Ali 2014). Pengukuran kinerja perusahaan dalam akuntansi basis akrual dilakukan dengan mencatat peristiwa-peristiwa ekonomi yang terjadi tanpa memperhatikan kapan transaksi kas terjadi (Mahat dan Ali 2014).

Institut Pertanian Bogor (IPB) merupakan salah satu perguruan tinggi negeri yang beralih status menjadi Perguruan Tinggi Negeri Badan Hukum (PTN Badan Hukum) sesuai dengan dengan amanat Undang-Undang Nomor 12 Tahun 2012 tentang Pendidikan Tinggi. Pasal 65 ayat 1 yang menyatakan bahwa Penyelenggaraan otonomi Perguruan Tinggi diberikan secara selektif berdasarkan evaluasi kinerja oleh Menteri kepada PTN dengan menerapkan Pola Pengelolaan Keuangan Badan Layanan Umum atau dengan membentuk PTN badan hukum untuk menghasilkan kualitas Pendidikan Tinggi yang baik. Pasal ini mengindikasikan bahwa suatu perguruan tinggi negeri yang memiliki statuta PTN Badan Hukum diberikan keleluasaan untuk menyelenggarakan pendidikan tinggi secara otonom di bidang akademik dan non akademik untuk menghasilkan pendidikan tinggi yang berkualitas dan terjangkau.

Salah satu akuntabilitas PTN Badan Hukum adalah Rektor menyusun laporan kinerja dan laporan keuangan PTN Badan Hukum pada setiap tahun anggaran untuk disampaikan kepada majelis wali amanat, dan Menteri yang menyelenggarakan urusan pemerintahan di bidang keuangan. Peraturan Pemerintah Nomor 66 tahun 2013 tentang Statuta IPB pasal 96 ayat 2 menyebutkan bahwa Akuntansi dan laporan keuangan diselenggarakan sesuai dengan Standar Akuntansi Keuangan yang diterbitkan oleh asosiasi profesi akuntansi Indonesia.

Akuntansi basis akrual belum sepenuhnya diterapkan oleh IPB. Penyusunan laporan keuangan IPB menggunakan basis akrual untuk pendapatan dan basis kas menuju akrual untuk aset, kewajiban, dan beban. Pengakuan aset tetap pada saat pembelian seharusnya diakui sebagai penambah aset tetap dan mengurangi kas jika dilakukan pembayaran secara tunai atau menambah utang jika pembelian dilakukan secara kredit. Aset tetap tersebut dengan berlalunya waktu harus disusutkan sesuai dengan umur ekonomisnya dan diakui sebagai beban penyusutan. Pengakuan basis akrual untuk komponen 
aset, kewajiban dan beban dalam laporan masih dilakukan secara manual pada akhir tahun atau pada saat penyusunan laporan keuangan melalui jurnal penyesuaian. Pencatatan transaksi pembelian persediaan juga masih diakui sebagai belanja persediaan. Perlakuan ini mengakibatkan sulitnya mengetahui posisi persediaan yang harus dilaporkan dalam laporan posisi keuangan.

Hasil Pemeriksaan Badan Pemeriksa Keuangan (BPK) Tahun 2014 menemukan bahwa penatausahaan persediaan di IPB belum dilaksanakan secara memadai sehingga nilai persediaan di neraca tidak menggambarkan nilai sebenarnya ${ }^{1}$. Dengan status otonom yang dimiliki oleh IPB, maka penerapan akuntansi basis akrual secara penuh merupakan hal yang tepat demi terciptanya tata kelola pemerintahan (good governance) yang lebih transparan dan akuntabel.

Pelaporan keuangan IPB PTN Badan Hukum harus mengikuti dua standar akuntansi, yaitu SAP dan SAK dengan menggunakan PSAK No. 45 tentang Pelaporan Keuangan Entitas Nirlaba dan SAK ETAP dimana kedua standar tersebut menggunakan basis akrual. Laporan keuangan berdasarkan PSAK 45 terdiri dari laporan posisi keuangan (neraca), laporan aktivitas, laporan arus kas dan catatan atas laporan keuangan.

Implementasi akuntansi basis akrual memerlukan berbagai persiapan yang komprehensif agar pelaksanaannya sesuai dengan tujuan yang ingin dicapai yaitu menyajikan Informasi laporan keuangan yang lebih lengkap untuk pengambilan keputusan serta ketepatan waktu dalam pelaporan. Asfiansyah (2015) menyatakan bahwa akuntansi basis akrual diyakini dapat menghasilkan laporan keuangan yang dapat dipercaya, akurat, komprehensif, dan relevan untuk pengambilan keputusan ekonomi, sosial dan politik. Untuk melaksanakan hal tersebut maka perlu dilakukan penelitian untuk mengetahui kondisi faktor-faktor yang berpengaruh dalam implementasi akuntansi basis akrual di IPB.

Sumber daya manusia memiliki peran penting yang mampu mempengaruhi keberhasilan suatu kebijakan. Penerapan sistem yang baru secara otomatis akan mengakibatkan perubahan pola kerja dan juga perubahan dalam proses bisnis institusi. Resistensi akan muncul karena pegawai sudah terbiasa dan nyaman dengan kondisi saat ini. Salah satu kunci keberhasilan implementasi akuntansi basis akrual adalah tingkat penerimaan karyawan terhadap sistem baru (Mahat dan Ali 2014). Langkah ini menghadapi sejumlah tantangan karena perubahan dari metode kas menjadi akuntansi akrual merupakan suatu perubahan sistem. Kesiapan karyawan untuk perubahan dapat dijelaskan sejauh menyangkut bagaimana individu karyawan memiliki pandangan positif tentang perlunya organisasi untuk berubah (Atan 2015).

Implementasi akuntansi basis akrual harus didukung oleh sistem akuntansi yang baik dan tepat. Sistem akuntansi akrual akan memberi informasi keuangan bagi pimpinan lembaga/instansi secara teratur (Hoesada 2010). Untuk menghasilkan informasi akuntansi yang mutakhir dan akurat maka sistem akuntansi yang ada harus dapat memenuhi kebutuhan terhadap penerapan akuntansi basis akrual.

\footnotetext{
1 Sumber: LHP BPK RI atas LKPP Tahun 2014, Ringkasan Eksekutif
} 
Komitmen organisasi juga memiliki peran penting dalam Implementasi akuntansi basis akrual. Komitmen karyawan dan pimpinan terhadap implementasi basis akuntansi yang baru dibutuhkan untuk menciptakan suasana yang kondusif dalam organisasi. Perjalanan menuju akuntansi basis akrual menekankan pada komitmen, dukungan penuh dan kerjasama dari semua orang yang diperlukan untuk membuat transisi mencapai tujuannya ( Mahadi et al. 2014). Hal ini dinyatakan pula oleh Mehrolhassani et al. (2015) bahwa untuk menerapkan akuntansi basis akrual perlu adanya komitmen, identifikasi masalah selama proses perubahan, dan mengubah budaya organisasi.

Hasil penelitian terdahulu tentang akuntansi basis akrual dilakukan Mehrolhassani et al. (2015) mengenai implementasi akuntansi basis akrual pada sektor kesehatan menggunakan analisis deskriptif dan Statistika inferensia (korelasi). Hasil penelitian menunjukkan bahwa Pelaksanaan akuntansi basis akrual menghadapi berbagai hambatan, terutama kepemimpinan, manajemen dan pegawai. Dengan demikian, pengembangan langkah-langkah efektif untuk mengatasi hambatan pelaksanaan harus menargetkan komponen ini .

Berdasarkan penjelasan tersebut maka kajian ini bertujuan untuk:

1. Mengetahui pemahaman, persepsi serta kesiapan sumber daya manusia di IPB terhadap akuntansi basis akrual.

2. Mengetahui kesiapan sistem akuntansi yang ada untuk mendukung penerapan akuntansi basis akrual.

3. Mengetahui komitmen organisasi dalam implementasi akuntansi akrual di Institut Pertanian Bogor.

4. Menentukan strategi yang tepat dalam rangka implementasi akuntansi basis akrual di Institut Pertanian Bogor.

\section{TINJAUAN PUSTAKA}

\section{Strategi}

Mulyadi (2007) mendefinisikan strategi sebagai suatu pengerahan dan pengarahan seluruh sumber daya perusahaan untuk perwujudan visi melalui misi perusahaan. Strategi membentuk pola pengambilan keputusan dalam mewujudkan visi perusahaan dengan strategi yang tepat seluruh sumber daya perusahaan dikerahkan menjadi kekuatan yang luar biasa besarnya untuk diarahkan ke pencapaian visi perusahaan, sehingga akan menjanjikan pencapaian visi perusahaan. Definisi strategi menurut Marrus (2002) adalah suatu proses penentuan rencana para pemimpin puncak yang berfokus pada tujuan jangka panjang organisasi, disertai penyusunan suatu cara atau upaya bagaimana agar tujuan tersebut dapat dicapai. Pengertian strategi lainnya diutarakan Craig dan Grant (1996) adalah penetapan sasaran dan tujuan yang diperlukan untuk mencapai sasaran dan tujuan.

Berdasarkan teori-teori tersebut dapat disintesiskan bahwa strategi adalah keterpaduan dari kegiatan yang direncanakan oleh institusi dan reaksi untuk mengantisipasi persaingan dan dinamika yang tidak terduga. Strategi juga merupakan sarana untuk mencapai suatu tujuan yang telah ditetapkan sebelumnya. 


\section{Akuntansi}

Akuntansi memiliki beberapa definisi yang berbeda, tergantung sudut pandang para ahli menilainya. Definisi menurut American Institute of Certified Public Accountants (AICPA) akuntansi adalah seni pencatatan, pengelompokan, pengikhtisaran menurut cara yang berarti dan dinyatakan dalam nilai mata uang semua transaksi serta kejadian yang bersifat finansial dan dari catatan itu dapat ditafsirkan hasilnya.

Pengertian akuntansi menurut Accounting Principle Board yang dikutip oleh Mahmudi (2011:92)

"Accounting is a service activity. Its function is to provide quantitative information, primarily financial in nature, about economic entities that is intended to be useful in making economic decisions".

Sementara menurut Grady $(2000: 12)$

Akuntansi adalah keseluruhan pengetahuan dan yang berhubungan dengan penciptaan, pengolahan, penyimpulan, penganalisaan, penafsiran, dan penyajian informasi yang dapat dipercaya dan penting artinya terhadap sistematika mengenai transaksi-transaksi yang bersifat keuangan dan diperlukan oleh pimpinan untuk operasi suatu badan dan untuk laporan yang harus diajukan guna mengenai hal tadi dan guna untuk memenuhi pertanggungjawaban yang bersifat keuangan atau lainnya.

Dari definisi tersebut dapat disimpulkan bahwa:

1. Akuntansi merupakan suatu seni, aktivitas jasa, pengetahuan, dan teknologi.

2. Fungsi akuntansi adalah menyediakan informasi kuantitatif terutama yang bersifat keuangan suatu entitas ekonomi.

3. Informasi yang dihasilkan merupakan suatu alat untuk membantu manajemen dalam mengambil keputusan.

\section{Akuntansi Pemerintahan}

Akuntansi pemerintahan menurut Mursyidi (2009) merupakan mekanisme akuntansi yang memproses transaksi keuangan yang berkaitan dengan pengelolaan keuangan Negara baik tingkat pusat maupun daerah. Sebagai suatu mekanisme akuntansi merupakan prosedur dalam penatausahaan dan pengelolaan keuangan Negara dan daerah.

Baswir (2000) menyatakan bahwa akuntansi pemerintahan (termasuk akuntansi untuk lembaga non profit pada umumnya) merupakan bidang akuntansi yang berkaitan dengan lembaga pemerintahan dan lembaga-lembaga yang bertujuan untuk tidak mencari laba.

\section{Basis Akuntansi}

Basis akuntansi merupakan standar akuntansi yang menetapkan kapan pengaruh atas transaksi atau kejadian harus diakui untuk tujuan pelaporan keuangan (Mursyidi 2009). Basis akuntansi ini berhubungan dengan waktu kapan pengakuan terhadap suatu transaksi keuangan dilakukan. Pengakuan, mengacu pada Kerangka Konseptual PP No. 71 Tahun 2010 adalah suatu proses yang 
menjadi dasar bahwa peristiwa atau kegiatan pengelolaan keuangan pusat maupun daerah layak untuk dicatat oleh entitas yang bersangkutan.

\section{Akuntansi Basis Kas}

Akuntansi basis kas merupakan basis akuntansi di mana pendapatan diakui, dicatat, dan dilaporkan apabila uang sudah diterima oleh kas; dan beban diakui, dicatat, dan dilaporkan apabila uang telah dikeluarkan dari kas (Mursyidi, 2009). Dalam akuntansi berbasis kas, transaksi ekonomi dan kejadian lain diakui ketika kas diterima atau dibayarkan. Inti dari metode ini adalah aliran kas (cash flow) fisik yang terjadi dalam suatu transaksi. Kelemahan utama dari basis ini adalah tidak selarasnya (matching) pendapatan dan biaya yang dikonsumsi untuk memperoleh pendapatan tersebut.

\section{Akuntansi Basis Kas Menuju Akrual}

Akuntansi basis kas menuju akrual (cash toward accrual) menurut PP No.24 tahun 2005 merupakan transisi yang dilakukan oleh pemerintah Indonesia sebelum beralih menuju akuntan basis akrual. Dalam Pengantar Standar Akuntansi Pemerintah (PSAP) dijelaskan bahwa pendapatan, belanja, dan pembiayaan dicatat berdasarkan basis kas sedangkan aset, utang, dan ekuitas dana dicatat berdasarkan basis akrual.

\section{Akuntansi Basis Akrual}

Konsep dasar akuntansi menurut Ikatan Akuntan Indonesia (IAI) dalam Kerangka Dasar Penyajian dan Pelaporan Keuangan (KDPPLK) paragraf 22 dan 23 menyatakan bahwa asumsi dasar akuntansi berdasarkan dasar akrual dan kelangsungan usaha (going concern). Akuntansi berbasis akrual berarti suatu basis akuntansi di mana transaksi ekonomi dan peristiwa-peristiwa lain diakui dan dicatat dalam catatan akuntansi dan dilaporkan dalam periode laporan keuangan pada saat terjadinya transaksi tersebut, bukan pada saat kas atau setara kas diterima atau dibayarkan.

Kelebihan akuntansi basis akrual yaitu menghasilkan laporan keuangan yang lebih baik untuk tujuan pengambilan keputusan. Akuntansi basis akrual juga membantu meningkatkan akuntabilitas pemerintah atas penggunaan seluruh sumber daya, seluruh aktiva dan kewajibannya yang diakui dalam laporan keuangan, pengalokasian sumber daya dapat lebih akurat, pengukuran penilaian biaya suatu program yang lebih baik, serta bermanfaat dalam mengevaluasi kinerja pemerintah terkait biaya jasa layanan sehingga mampu meningkatkan efisiensi (Bastani et al. 2012). Kelemahan dari akuntansi basis akrual yaitu kompleksitasnya yang tinggi dibanding basis akuntansi kas sehingga membutuhkan Sumber daya manusia dengan kompetensi akuntansi yang memadai.

\section{Penerapan Akuntansi Basis Akrual}

Akuntansi basis akrual mendasarkan konsepnya pada dua pilar yaitu 1) pengakuan pendapatan dimana pendapatan dicatat pada saat pemerintah mempunyai hak untuk melakukan penagihan dari hasil kegiatan, dan 2) pengakuan beban dilakukan pada saat kewajiban untuk membayar sudah terjadi.

Contoh transaksi yang membedakan basis kas dan basis akrual adalah dalam penerbitan Surat Ketetapan Pajak (SKP) oleh Direktorat Jenderal Pajak. Dalam akuntansi basis kas, saat terbitnya SKP 
tersebut tidak diakui sebagai pendapatan, karena kas belum diterima. Namun, dalam basis akrual, terbitnya SKP tersebut oleh Direktorat Jenderal Pajak harus sudah diakui sebagai pendapatan, walaupun kas belum diterima atas pendapatan pajak tersebut.

Penerapan konsep pengakuan pendapatan di IPB dilakukan pada saat pengisian Kartu Rencana Studi (KRS) oleh mahasiswa. Pengisian KRS ini menjadi dasar bagi IPB untuk mengakui tagihan SPP kepada mahasiswa sesuai dengan mata kuliah yang diambil oleh mahasiswa dalam semester tersebut.

Konsep akrual juga berkaitan dengan belanja barang atau jasa yang masih harus dibayar. Jenis belanja ini dapat terdiri dari belanja barang/jasa yang masih harus dibayar yaitu kewajiban yang timbul akibat hak atas pengeluaran anggaran yang dilakukan oleh kementerian negara/lembaga/pemerintah daerah untuk membiayai keperluan kantor, pengadaan barang yang habis pakai, pengadaan/penggantian inventaris kantor dan langganan daya dan jasa. Dokumen sumber yang terkait berupa tagihan dari penyedia barang/jasa, Surat Keputusan Pembentukan Tim, Berita Acara Serah Terima (BAST) barang/jasa dan dokumen pendukung lainnya menjadi dasar untuk mengakui belanja atau beban pada periode tersebut.

\section{Perguruan Tinggi Negeri Badan Hukum}

Undang-Undang Nomor 12 Tahun 2012 Tentang Pendidikan Tinggi merupakan suatu bentuk pemberian keleluasaan dan kewenangan kepada Perguruan Tinggi dalam menciptakan pendidikan yang berkualitas. Reformasi pendidikan tinggi di Indonesia dimulai dari proses pemberian otonomi pada tujuh institusi pendidikan tinggi negeri di Indonesia. Proses otonomi tersebut sudah dimulai sejak munculnya Peraturan Pemerintah Nomor 61 Tahun 1999, tentang Penetapan Perguruan Tinggi Negeri sebagai Badan Hukum. Konsep Badan Hukum Milik Negara (BHMN) yang dilandasi oleh PP No. 61/1999 ini memberikan otonomi bagi Perguruan Tinggi Negeri (PTN) yang berubah menjadi BHMN. Beberapa perguruan tinggi yang memperoleh status otonomi tersebut antara lain UI, UGM, IPB, ITB, USU, UPI, dan Unair.

\section{Standar Akuntansi Pemerintahan (SAP)}

Peraturan Pemerintah No. 71 Tahun 2010 tentang Standar Akuntansi Pemerintah menjelaskan bahwa Standar Akuntansi Pemerintah adalah prinsip-prinsip akuntansi yang diterapkan dalam menyusun dan menyajikan laporan keuangan pemerintah. Dengan demikian, SAP merupakan pernyataan yang mempunyai kekuatan hukum dalam upaya meningkatkan kualitas laporan keuangan pemerintah di Indonesia.

Pasal 1 ayat (8) menyatakan bahwa yang dimaksud dengan SAP basis akrual adalah SAP yang mengakui pendapatan, beban, aset, utang, dan ekuitas dalam pelaporan finansial basis akrual, serta mengakui pendapatan, belanja, dan pembiayaan dalam pelaporan pelaksanaan anggaran berdasarkan basis yang ditetapkan dalam APBN atau APBD. SAP Berbasis Akrual tersebut dinyatakan dalam bentuk PSAP dan dilengkapi dengan Kerangka Konseptual Akuntansi Pemerintahan. 


\section{Standar Akuntansi Keuangan (SAK)}

Standar Akuntansi Keuangan (SAK) menurut PSAK 25 Revisi 2009 paragrap 5 adalah Pernyataan dan Interpretasi yang dikeluarkan oleh Dewan Standar Akuntansi Keuangan Ikatan Akuntan Indonesia serta peraturan regulator pasar modal untuk entitas yang berada di bawah pengawasannya. SAK merupakan suatu kerangka dalam prosedur pembuatan laporan keuangan agar terjadi keseragaman dalam penyajian laporan keuangan. Standar Akuntansi Keuangan (SAK) merupakan hasil perumusan Komite Prinsipil Akuntansi Indonesia pada tahun 1994.

\section{METODE PENELITIAN}

Metode pengumpulan data dalam penelitian ini dilakukan penelitian survei, yaitu menggunakan kuesioner skala likert kepada responden yang telah ditentukan. Responden dari penelitian ini adalah pegawai Biro keuangan, Pengelola Kas Unit (PKU) dan Kepala Tata Usaha (KTU) di Institut Pertanian Bogor. Dari populasi yang ada, diambil responden sebagai sampel. Sampel adalah himpunan bagian dari populasi yang dapat mewakili sifat-sifat populasi. Metode penentuan sampel menggunakan teknik Purposive sampling menggunakan rumus Slovin dengan kesalahan 5\%.

Tabel 1 Jumlah sampel penelitian

\begin{tabular}{llcc}
\hline No & \multicolumn{1}{c}{ Lapisan } & Anggota Populasi & Jumlah Sampel \\
\hline 1 & Pegawai Biro Keuangan & 30 & 28 \\
2 & Pemegang Kas Unit Kerja & 129 & 98 \\
3 & Kepala Tata Usaha & 50 & 44 \\
\hline & Jumlah & 209 & 170 \\
\hline
\end{tabular}

Uji Validitas

Validitas menunjukkan sejauh mana ketepatan dan kecermatan suatu alat ukur dalam melakukam fungsi ukurannya. Uji validitas digunakan untuk mengukur sah, atau valid tidaknya suatu kuesioner. Suatu kuesioner dikatakan valid jika pertanyaan pada kuesioner mampu untuk mengungkapkan sesuatu yang akan diukur oleh kuesioner tersebut. Uji validitas dilakukan dengan menggunakan Pearson product moment.

\section{Uji Reliabilitas}

Reliabilitas adalah indeks yang menunjukkan sejauh mana suatu alat pengukur dapat dipercaya atau dapat diandalkan. Apabila suatu alat pengukur dipakai beberapa kali untuk mengukur gejala yang sama dan hasil yang diperoleh relatif konsisten maka alat pengukur tersebut reliabel. Pengukuran reliabilitas dilakukan menggunakan alpha cronbach. Jika alpha cronbach lebih besar atau sama dengan 0,60 maka suatu variabel reliabel.

\section{Analisis Koefisien Korelasi Rank Spearman}

Korelasi Rank Spearman digunakan untuk menguji hipotesis asosiatif antarvariabel jika data yang digunakan memiliki skala ordinal Sugiono (2008). Analisis ini untuk mengetahui ada atau tidaknya hubungan antara dua variabel yang akan diuji.

Uji hipotesis dilakukan untuk melihat adanya hubungan yang signifikan antar variabel. Jika nilai $p$-value $<0.05$, maka dapat disimpulkan terdapat hubungan yang signifikan pada dua variabel yang 
diuji. Sebaliknya, jika nilai $p$-value $>0.05$, maka dapat disimpulkan bahwa tidak terdapat hubungan yang signifikan pada dua variabel yang diuji.

\section{Metode Analisis Deskriptif}

Analisis deskriptif merupakan suatu metode analisis sederhana yang dapat digunakan untuk menggambarkan kondisi suatu observasi dengan menyajikannya dalam bentuk Tabel, grafik maupun narasi dengan tujuan untuk memudahkan pembaca dalam menafsirkan hasil observasi. Untuk menentukan panjang kelas interval digunakan rumus sebagai berikut:

Skor minimum $\quad=1$

Skor maksimum $\quad=5$

Interval/rentang $=$ Skor maksimum - Skor minimum, $5-1=4$

Banyak kelas/jenjang $=5$

Jarak interval = Interval $/$ jenjang $, 4 / 5=0,8$

Dengan menggunakan pedoman tersebut tingkat jawaban responden pada setiap item pertanyaan dengan tafsiran daerah sebagai berikut:

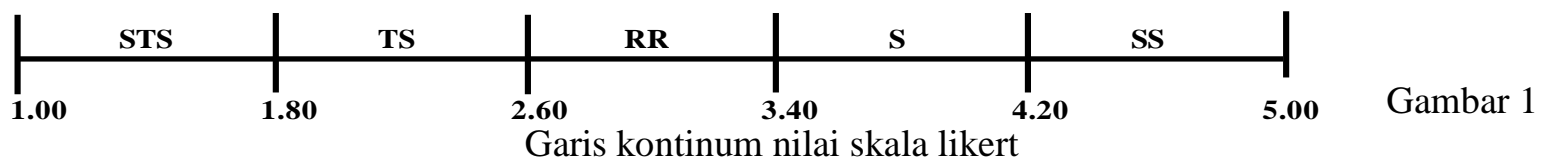

Kriteria persentase skor terhadap skor ideal dapat dilihat dalam tabel 2.

Tabel 2 Persentase skor terhadap skor ideal

\begin{tabular}{cll}
\hline No. & \multicolumn{1}{c}{ \% Jumlah Skor } & Kriteria \\
\hline 1 & $20.00-36.00$ & Sangat Tidak Setuju \\
2 & $36.01-52.00$ & Tidak Setuju \\
3 & $52.01-68.00$ & Ragu-ragu \\
4 & $68.01-84.00$ & Setuju \\
5 & $84.01-100$ & Sangat Setuju \\
\hline
\end{tabular}

Sumber : Sugiono (2010)

\section{Proses Hierarki Analitis (AHP)}

Proses Hirarki analitis / Analytic Hierarchy Process ( AHP ) adalah teori pengukuran melalui perbandingan berpasangan dan bergantung pada penilaian ahli untuk menurunkan skala prioritas (Saaty 1993). AHP merupakan metode pengambilan keputusan dari suatu masalah multifaktor yang kompleks yang disusun menjadi suatu hirarki dengan menguraikan keputusan dalam langkah-langkah berikut: (1) Mendefinisikan masalah; (2) Menentukan hirarki keputusan; (3) Menggunakan prioritas dari perbandingan untuk menimbang prioritas; (4) Menghitung matriks pendapat individu; (5) Menghitung matriks pendapat gabungan menggunakan rata-rata geometrik; (6) Sintesis dan (7) Konsistensi.

GAMBARAN UMUM 
Institut Pertanian Bogor (IPB) merupakan Penyelenggara Pendidikan Tinggi Milik Negara, yang didirikan untuk pertama kali sejak tanggal 1 September 1963 berdasarkan Keputusan Menteri Perguruan Tinggi Ilmu Pengetahuan Nomor 91 tahun 1963. Keputusan Menteri tersebut kemudian dikukuhkan dengan Keputusan Presiden Republik Indonesia No. 279 tahun 1965. Pada tahun 2000 dengan Peraturan Pemerintah Nomor 154 tanggal 26 Desember 2000 (Lembaran Negara tahun 2000 Nomor 272) Institut Pertanian Bogor ditetapkan sebagai Badan Hukum Milik Negara (BHMN) yang bersifat nirlaba.

Undang-undang (UU) Nomor 12 tahun 2012 tentang pendidikan tinggi yang mengatur mengenai penyelenggaraan pendidikan tinggi di Indonesia dimana IPB ditetapkan sebagai Perguruan Tinggi Negeri Badan Hukum. Implementasinya didukung dengan PP nomor 58 tahun 2013 tentang Bentuk dan Mekanisme Pendanaan PTN Badan Hukum dan PP Nomor 66 Tahun 2013 mengenai Statuta IPB. Selanjutnya terbit Peraturan Pemerintah Nomor 26 tahun 2015 atas revisi PP sebelumnya tentang Bentuk dan Mekanisme Pendanaan PTN Badan Hukum.

\section{Organisasi IPB}

Berdasarkan Undang-undang No.12 tahun 2012 yang menetapkan IPB sebagai Perguruan Tinggi Negeri badan hukum dan draft Peraturan Pemerintah mengenai Penyelenggaraan Pendidikan Tinggi dan Tatakelola Perguruan Tinggi, serta mengacu pada Ketetapan MWA Nomor 17/MWAIPB/2003 tentang Anggaran Rumah Tangga IPB, melalui Ketetapan MWA Nomor 125/MWAIPB/2013, organisasi IPB terdiri atas organ: (i) penentu yang terdiri atas Majelis Wali Amanat (MWA) dan Senat Akademik, (ii) pengelola yaitu Rektor dan Wakil Rektor, (iii) Pelaksana akademik terdiri atas fakultas, sekolah pascasarjana, program pendiidkan khusus, lembaga penelitian dan pengabdian kepada masyarakat, departemen dan pusat, (iv) Pelaksana administrasi yaitu direktorat, kantor, dan biro, dan (v) penunjang yang meliputi perpustakaan, bagian/laboratorium, bengkel, rumah sakit hewan, kebun universitas (university farm), satuan usaha, satuan keamanan dan ketertiban, dan bentuk lainnya.

\section{Pola Pengelolaan IPB}

Otonomi perguruan tinggi yang diamanatkan oleh Undang-Undang Nomor 12 Tahun 2012 dalam Pasal 64 adalah otonomi pengelolaan perguruan tinggi aspek akademik dan aspek non akademik. Otonomi akademik berkaitan dengan misi perguruan tinggi untuk mencari kebenaran tanpa dipengaruhi oleh kekuatan ekonomi maupun politik. Untuk dapat menyelenggarakan otonomi akademik ini diperlukan adanya otonomi non akademik yakni tata kelola sebagai keleluasaan dan keluwesan dalam mengatur perguruan tinggi tanpa campur tangan kepentingan politik maupun ekonomi, termasuk tata kelola keuangannya.

IPB menerapkan Kebijakan sistem Sentralisasi Administrasi Desentralisasi Akademik dan Riset (SADAR). Kebijakan ini merupakan paradigma baru otonomi dan akuntabilitas dalam menerapkan prinsip good university management dalam sistem keuangan. Pencapaian SADAR bidang keuangan di IPB dengan cara sentralisasi (manajemen satu pintu) dalam pengelolaan, penerimaan, penggunaan dan 
pelaporam keuangan oleh Biro Keuangan IPB. Unit kerja melakukan proses planning, programming, and budgeting dalam melaksanakan anggaran, dan unit kerja mempunyai Pemegang Kas Unit (PKU). IPB juga menetapkan kebijakan dimana seluruh penerimaan dari pusat pendapatan tercatat di Biro Keuangan IPB.

\section{Uji validitas}

\section{HASIL DAN PEMBAHASAN}

Hasis analisis data berupa angka korelasi ( $\mathrm{r}$ hitung) yang kemudian diandingkan dengan $\mathrm{r}$ tabel, di mana $r$ tabel untuk responden sebanyak 140 adalah sebesar 0,166 . Berdasarkan hasil olah data dengan bantuan software SPSS versi 16 for windows, diketahui bahwa masing-masing item yang menyusun masing-masing kuesioner memiliki $r_{\text {hitung }}>r_{\text {tabel }}$, yang berarti masing-masing item dari variabel sumber daya manusia, akuntansi, dan komitmen organisasi adalah valid. Dengan demikian syarat validitas dari alat ukur terpenuhi.

\section{Uji Reliabilitas}

Uji reliabilitas digunakan untuk mengukur kehandalan suatu kuesioner yang merupakan indikator dari variabel atau konstruks yang dilakukan. Hasil pengolahan data menunjukan bahwa variabel sumber daya manusia, akuntansi, dan komitmen organisasi memiliki nilai cronbach alpha lebih besar dari 0,60.

Tabel 2 Hasil analisis uji reliabilitas

\begin{tabular}{lrr}
\hline Faktor & Cronbach alpha & N of Items \\
\hline Sumberdaya Manusia & 0,865 & 14 \\
Sistem Akuntansi & 0,909 & 13 \\
Komitmen Organisasi & 0,847 & 18 \\
\hline
\end{tabular}

Sumber: Data diolah (2016)

\section{Analisis Koefisien Korelasi Rank Spearman}

Hasil Korelasi rank spearman digambarkan dalam tabel berikut:

Tabel 3 Hasil analisis uji korelasi rank Spearman

\begin{tabular}{|c|c|c|c|c|c|}
\hline & & & Sumberdaya Manusia & Sistem Akuntansi & $\begin{array}{l}\text { Komitmen } \\
\text { Organisasi }\end{array}$ \\
\hline \multirow{12}{*}{$\begin{array}{l}\text { Spearman's } \\
\text { tho }\end{array}$} & Sumberdaya Manusia & Correlation & 1000 & $270(* *)$ & 149 \\
\hline & & Coefficient & 1.000 & .2101 & .141 \\
\hline & & Sig. (2-tailed) & & .001 & .078 \\
\hline & & $\mathrm{N}$ & 140 & 140 & 140 \\
\hline & Sistem Akuntansi & Correlation & $270(* *)$ & 1000 & $219(* *)$ \\
\hline & & Coefficient & $.2 / 0\left({ }^{2}\right)$ & 1.000 & 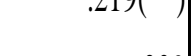 \\
\hline & & Sig. (2-tailed) & .001 & & .009 \\
\hline & & $\mathrm{N}$ & 140 & 140 & 140 \\
\hline & Komitmen Organisasi & Correlation & 149 & $219(* *)$ & 1000 \\
\hline & & Coefficient & .149 & & 1.000 \\
\hline & & Sig. (2-tailed) & .078 & .009 & \\
\hline & & $\mathrm{N}$ & 140 & 140 & 140 \\
\hline
\end{tabular}


* signifikan pada $\alpha=0.05 ; * *$ signifikan pada $\alpha=0.01$

Sumber: Data diolah (2016)

Tabel 4 menunjukkan adanya hubungan yang signifikan antara sumber daya manusia dengan akuntansi ( $\mathrm{p}$-value $<0,01$ ). Tabel tersebut juga menunjukkan tidak adanya hubungan yang signifikan antara sumber daya dengan komitmen organisasi (p-value > 0,05), namun ada hubungan antara akuntansi dengan komitmen organisasi (p-value < 0,01). Berdasarkan nilai korelasi diketahui bahwa hubungan antara sumber daya manusia dengan dengan akuntansi tergolong rendah yaitu sebesar 0,270, dan hubungan antara akuntansi dengan komitmen organisasi juga tergolong rendah yaitu sebesar 0,219. Hasil penelitian ini secara parsial sejalan dengan Bal, et al. (2014) yang menyatakan tidak ada hubungan antara komitmen afektif dimensi komitmen organisasi dan kompensasi dan manfaat dimensi manajemen sumber daya manusia. Penelitian ini juga menyatakan bahwa tidak ada hubungan antara komitmen kontinyu dimensi komitmen dan manajemen sumber daya manusia praktik organisasi.

\section{Analisis rating scale}

\section{Sumber daya Manusia}

Pengolahan data kuesioner menghasilkan jumlah skor total yang diperoleh terhadap keseluruhan faktor sumber daya manusia sebesar 7.008 (71,51\%). Hasil yang diperoleh berdasarkan garis kontinum menunjukan bahwa secara keseluruhan faktor sumber daya manusia yang terlibat langsung dengan pengelolaan keuangan dan akuntansi basis akrual di IPB berada pada kriteria setuju. Berdasarkan skala likert nilai tersebut sama dengan 3,58 (skala 5).

Jumlah skor total yang diperoleh terhadap 4 pertanyaan indikator pemahaman sebesar 1.895 $(67,68 \%)$. Hasil yang diperoleh berdasarkan garis kontinum menunjukan bahwa secara keseluruhan pemahaman berada pada kriteria ragu-ragu. Berdasarkan skala likert nilai tersebut sama dengan 3,38 (skala 5).

Persepsi responden terhadap akuntansi basis akrual diperoleh dari hasil pengisian kuesioner pada keseluruhan unsur persepsi sebesar 3.679 (75,08\%). Hasil yang diperoleh menunjukan secara keseluruhan persepsi berada pada kriteria setuju. Berdasarkan skala likert nilai tersebut sama dengan 3,75 (skala 5).

Kesiapan responden terhadap implementasi akuntansi basis akrual memperoleh skor sebesar $1.434(68,29 \%)$. Hasil yang diperoleh berdasarkan garis kontinum menunjukan bahwa kesiapan Sumberdaya manusia berada pada kriteria setuju. Berdasarkan skala likert nilai tersebut sama dengan 3,41 (skala 5).

\section{Sistem Akuntansi}

Jumlah skor total yang diperoleh dari hasil pengisian kuesioner pada Sistem akuntansi IPB sebesar 6.245 (68,63\%). Hasil yang diperoleh berdasarkan garis kontinum menunjukan bahwa secara keseluruhan responden setuju bahwa sistem akuntansi sudah baik dan dapat digunakan untuk akuntansi basis akrual. Berdasarkan skala likert nilai tersebut sama dengan 3,43 (skala 5).

Berdasarkan hasil pengolahan data skor total yang diperoleh untuk keseluruhan elemen neraca sebesar $4.188(66,48 \%)$. Hasil yang diperoleh berdasarkan garis kontinum menunjukan bahwa secara 
keseluruhan responden menyatakan ragu-ragu bahwa subsistem aset, kewajiban dan ekuitas sudah dapat digunakan untuk implementasi akuntansi basis akrual. Berdasarkan skala likert nilai tersebut sama dengan 3,32 (skala 5).

Jumlah skor yang diperoleh untuk laporan aktivitas sebesar 2.057 (73,46\%). Hasil yang diperoleh berdasarkan garis kontinum menunjukan bahwa responden setuju subsistem laporan aktivitas IPB sudah baik dan mendukung akuntansi basis akrual. Berdasarkan skala likert nilai tersebut sama dengan 3,67 (skala 5).

\section{Komitmen Organisasi}

Pengolahan data untuk komitmen organsisasi menghasilkan total skor sebesar $8.744(69,40 \%)$. Hasil yang diperoleh berdasarkan garis kontinum menunjukan bahwa secara keseluruhan komitmen organisasi IPB sudah baik. Hal ini terlihat dari nilai yang berada pada kriteria setuju. Berdasarkan skala likert nilai tersebut sama dengan 3,47 (skala 5).

Jumlah skor yang diperoleh dari hasil pengisian kuesioner pada keseluruhan unsur komitmen afektif sebesar 3.175 (75,60\%). Hasil yang diperoleh berdasarkan garis kontinum menunjukan secara keseluruhan komitmen afektif (keinginan) berada dalam kriteria setuju. Berdasarkan skala likert nilai tersebut sama dengan 3,78 (skala 5). Secara umum responden memiliki keterikatan yang tinggi dan ingin tetap berada di dalam organisasi.

Pengolahan data untuk keseluruhan unsur komitmen keberlanjutan menghasilkan skor sebesar $2.810(66,90 \%)$. Hasil yang diperoleh berdasarkan garis kontinum menunjukan secara keseluruhan komitmen keberlanjutan (kebutuhan) berada dalam kriteria ragu-ragu. Berdasarkan skala likert nilai tersebut sama dengan 3,35 (skala 5).

Berdasarkan hasil pengolahan data jumlah skor total yang diperoleh untuk keseluruhan unsur komitmen normatif sebesar 2.759 (65,69\%). Hasil yang diperoleh dalam garis kontinum menunjukan bahwa secara keseluruhan komitmen normatif (tanggung jawab) berada dalam kriteria ragu-ragu. Berdasarkan skala likert nilai tersebut sama dengan 3,28 (skala 5).

\section{Implementasi Akuntansi Basis Akrual}

Penentuan alternatif kebijakan yang dapat diambil dilakukan berdasarkan hasil identifikasi terhadap kondisi faktor sumber daya manusia, sistem akuntansi dan komitmen organisasi. Alternatif kebijakan yang dapat diterapkan yaitu: (1) Rekruitmen; (2) Sosialisasi; (3) Pengembangan sistem; (4) Petunjuk operasional baku dan (5) Pendidikan dan pelatihan.

Responden ahli (expert) dipilih secara sengaja berdasarkan posisi dan perannya sebagai penentu arah dan kebijakan berkaitan dengan implementasi akuntansi basis akrual. Rasio Konsistensi pendapat

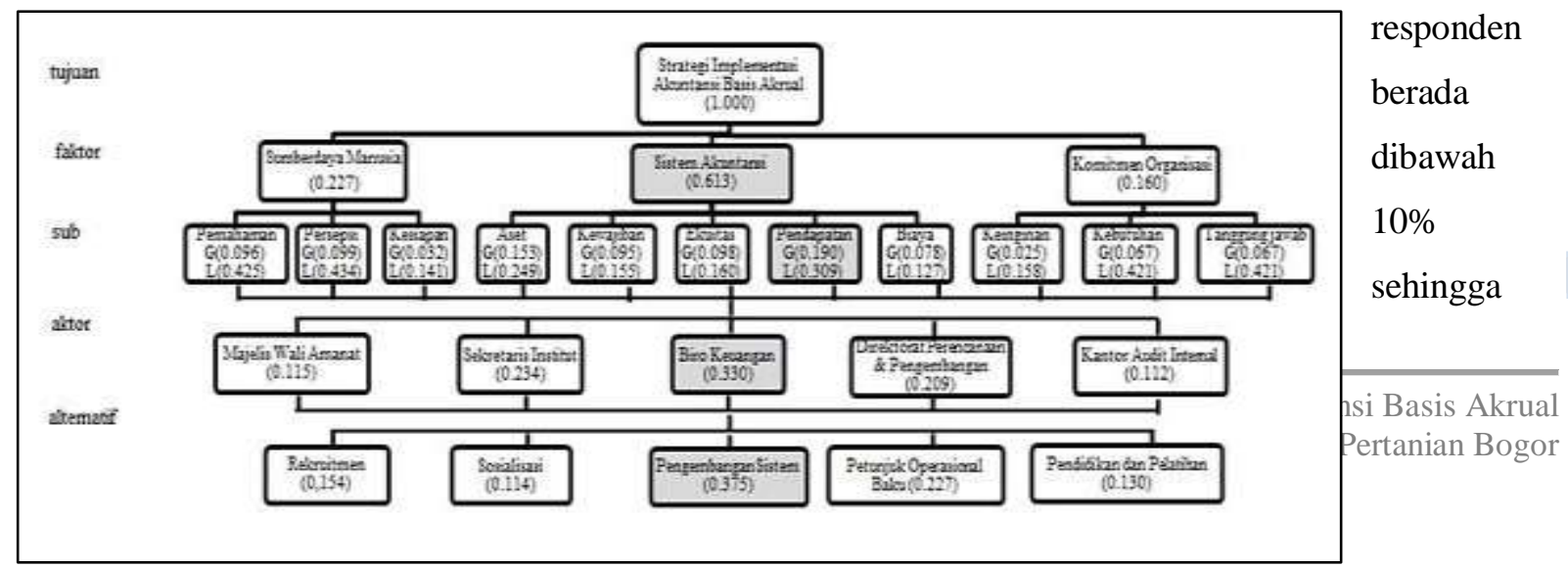


validitas penilaian bisa dipertangggungjawabkan. Hasil perhitungan pendapat gabungan dan hasil pengolahan AHP menggunakan Expert Choice 11.

Gambar 2 Struktur hirarki implementasi akuntansi basis akrual IPB

Hasil pengolahan data menunjukkan bahwa untuk menerapkan akuntansi basis akrual di IPB faktor sistem akuntansi memiliki bobot nilai 0,613, sumber daya manusia memiliki bobot nilai 0,227 dan komitmen organisasi memiliki bobot nilai 0,160. Dengan demikian urutan prioritas yang lebih diutamakan dalam implementasi akuntansi basis akrual adalah sistem akuntansi.

Bobot nilai tertinggi untuk subsitem akuntansi adalah subsistem pendapatan dengan nilai bobot 0,309 , kemudian subsistem aset dengan nilai bobot 0,249, subsistem ekuitas (aktiva bersih) dengan nilai bobot 0,160 , subsistem kewajiban dengan nilai bobot 0,155 dan subsistem biaya dengan nilai bobot 0,127 .

Bobot nilai teringgi untk subfaktor sumber daya manusia adalah subfaktor persepsi dengan nilai bobot 0,434 , kemudian berikutnya subfaktor pemahaman dengan nilai bobot 0,425 dan subfaktor kesiapan dengan nilai bobot 0,141. Dalam implementasi suatu sistem baru persepsi pegawai terhadap sistem tersebut merupakan hal yang utama.

Penilaian untuk subfaktor Komitmen organisasi menunjukkan bahwa subfaktor kebutuhan dan tanggung jawab memiliki nilai bobot yang sama yaitu 0,421 dan keinginan memiliki bobot 0,158 . Dengan demikian prioritas adalah kebutuhan dan tanggung jawab.

Hasil penilaian responden untuk aktor dalam implementasi akuntansi basis akrual menunjukkan bahwa Biro Keuangan memiliki nilai bobot nilai 0,330, Sekretaris Institut memiliki bobot nilai 0,234, Direktorat Perencanaan dan Pengembangan memiliki bobot nilai 0,209, Majelis Wali Amanat memiliki bobot nilai 0,115 dan Kantor Audit Internal memiliki bobot nilai 0,112. Dengan demikian prioritas utama dalam implementasi akuntansi basis akrual adalah biro keuangan.

Hasil dari penilaian alternatif kebijakan menunjukkan bahwa pengembangan sistem memiliki nilai bobot 0,375 , kemudian Petunjuk operasional baku memiliki nilai bobot 0,227 , rekruitmen memiliki nilai bobot 0,154 , pendidikan dan pelatihan memiliki nilai bobot 0,130 dan sosialisasi memiliki nilai bobot 0,114 . Dengan demikian dalam implementasi akuntansi basis akrual di IPB, alternatif kebijakan yang paling utama adalah pengembangan sistem.

Tabel 4 Matriks dan bobot alternatif menggunakan rata-rata geometri

\begin{tabular}{|c|c|c|c|c|c|c|}
\hline Pilihan & Rekruitmen & Sosialisasi & $\begin{array}{c}\text { Pengemban } \\
\text { gan Sistem }\end{array}$ & $\begin{array}{c}\text { Petunjuk } \\
\text { Operasional } \\
\text { Baku }\end{array}$ & $\begin{array}{c}\text { Pendidikan } \\
\text { dan } \\
\text { Pelatihan }\end{array}$ & Bobot \\
\hline Rekruitmen & 1,00 & 1,09 & 0,38 & 0,72 & 1,51 & 0,154 \\
\hline Sosialisasi & 0,92 & 1,00 & 0,33 & 0,45 & 0,86 & 0,114 \\
\hline $\begin{array}{c}\text { Pengembangan } \\
\text { Sistem }\end{array}$ & 2,64 & 3,07 & 1,00 & 1,90 & 2,26 & $\mathbf{0 , 3 7 5}$ \\
\hline $\begin{array}{c}\text { Petunjuk } \\
\text { Operasional Baku }\end{array}$ & 1,38 & 2,21 & 0,53 & 1,00 & 1,84 & 0,227 \\
\hline $\begin{array}{c}\text { Pendidikan dan } \\
\text { Pelatihan }\end{array}$ & 0,66 & 1,16 & 0,44 & 0,54 & 1,00 & 0,130 \\
\hline
\end{tabular}

Sumber: Data diolah (2016) 


\section{Strategi Implementasi}

Berdasarkan hasil AHP dan wawancara dengan responden maka rumusan strategi dalam implementasi akuntansi basis akrual di IPB disusun sebagai berikut:

\section{Pengembangan sistem,}

Fokus utama dari pengembangan sistem adalah membangun subsistem yang mampu memenuhi kebutuhan organisasi berdasarkan bobot prioritas, yaitu: (a) Subsistem pendapatan, (b) Subsistem aset, (c) Subsistem ekuitas (Aktiva Bersih), (d) Subsistem kewajiban (utang), dan (e) Subsistem beban. Amirya, et al. (2012) menyatakan bahwa pengembangan sistem akan mendorong terjadinya perubahan organisasi, mencakup perubahan nilai-nilai manajemen, Sumber daya manusia, prosedural, teknologi dan struktur organisasi.

\section{Penyusunan Petunjuk Operasional Baku (POB)}

Peningkatan efisiensi dan efektifitas pelaksanaan akuntansi basis akrual maka perlu adanya perubahan tatalaksana prosedur full-paper menuju tatalaksana paper-less melalui penggunaan teknologi informasi dan komunikasi.

\section{Rekruitmen}

Rekruitmen menjadi salah satu kebijakan untuk memenuhi kebutuhan terhadap sumber daya manusia untuk pemisahan fungi perbendaharaan dan fungsi akuntansi.

\section{Pendidikan dan Pelatihan}

Pendidikan dan pelatihan berkaitan dengan peningkatan kemampuan pegawai, khususnya yang terlibat dalam pengelolaan dan pelaporan keuangan untuk melaksanakan akuntansi basis akrual. Langelo, et al. (2012) menyatakan bahwa peningkatan kemampuan Sumber daya manusia yang kompeten melalui pelatihan dan sosialisasi, diharapkan dapat menunjang kesiapan pemerintah Kota Bitung untuk menerapkan SAP Berbasis Akrual dalam menyajikan laporan keuangan.

\section{Sosialisasi}

Sosialisasi dilakukan terutama bagi seluruh pengelola keuangan di unit kerja dengan mengundang narasumber dari Kementerian Keuangan dan IAI.

\section{Perancangan Program}

Perancangan program Untuk melaksanakan strategi utama disusun sebagai berikut:

Tabel 5 Perancangan program pengembangan sistem akuntansi basis akrual

$\begin{array}{llll}\text { Strategi } & \text { Kebijakan } & \text { Program } & \text { Tahapan }\end{array}$




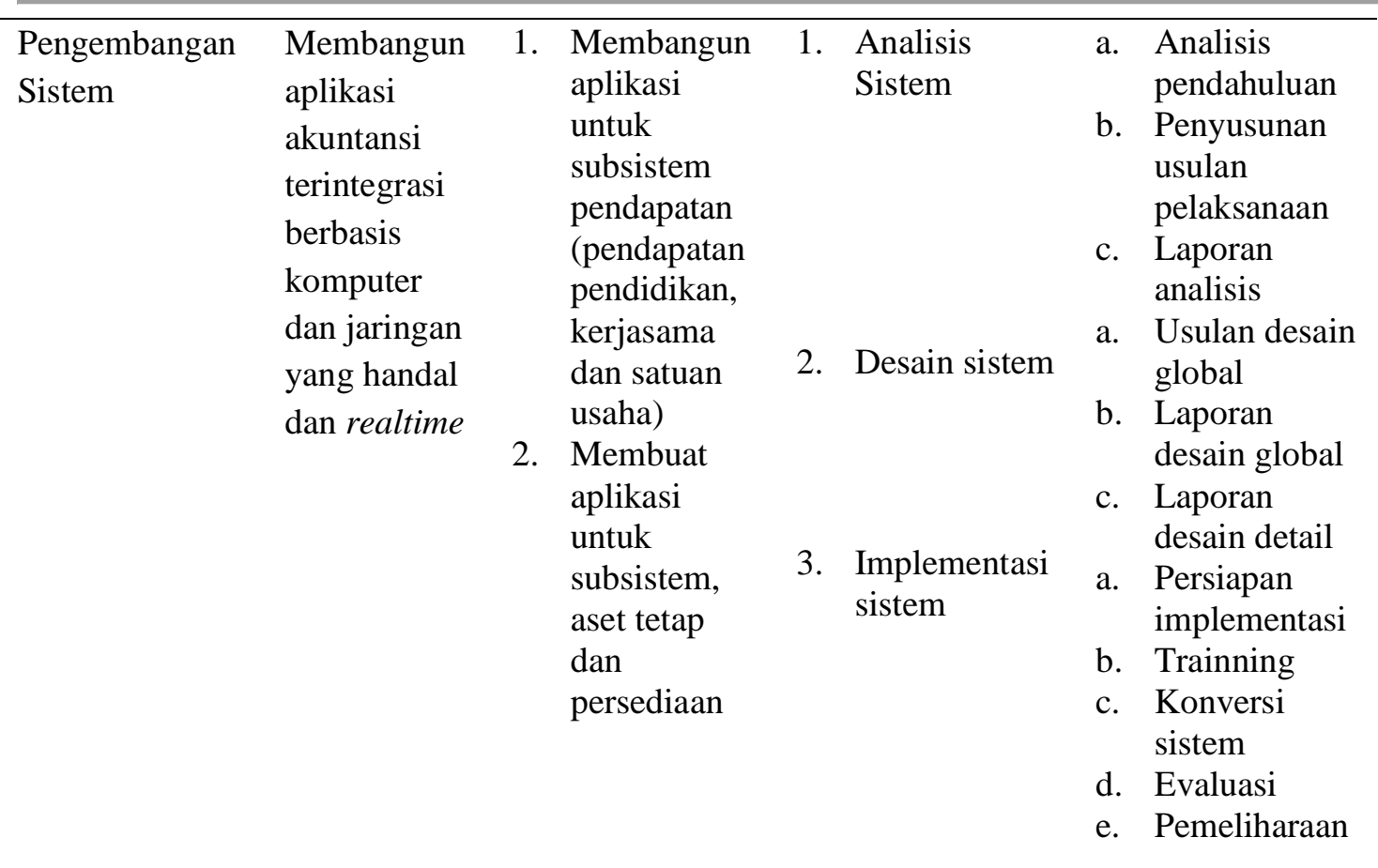

\section{SIMPULAN DAN SARAN}

\section{Simpulan}

Tingkat pemahaman sumberdaya manusia di IPB mengenai akuntansi basis akrual masih dalam kondisi ragu-ragu, sementara persepsi setuju dan kesiapan sumberdaya manusia setuju untuk implementasi akuntansi basis akrual.

1. Subsistem aset sebagai bagian dari sistem akuntansi yang ada di IPB belum siap untuk menerapkan akuntansi basis akrual.

2. Komitmen afektif (keinginan) dalam kriteria setuju, sementara komitmen kebutuhan dan tanggung jawab dalam kriteria ragu-ragu.

3. Strategi yang dipilih dalam implementasi akuntansi basis akrual di IPB adalah pengembangan sistem, yaitu pengembangan sistem akuntansi.

\section{Saran}

Pengembangan sistem dengan memprioritaskan pada subsistem pendapatan dan aset tetap serta persediaan, Pengembangan sistem sebaiknya melibatkan pihak luar yang kompeten dalam membangun sistem akuntansi, Saran untuk penelitian selanjutnya yaitu agar memperluas lingkup penelitian sehingga dapat memberikan kontribusi yang lebih berarti dalam penerapan akuntansi basis akrual khususnya untuk PTN Badan Hukum, termasuk faktor lain yang berpengaruh.

\section{DAFTAR PUSTAKA}

Amirya M, Djamhuri A, Ludigdo U. 2012. Pengembangan Sistem Anggaran dan Akuntansi Badan Layanan Umum Universitas Brawijaya: Perspektif Institusionalis, Jurnal Akuntansi Multiparadigma, 3(3): 343-356

Arif B. 2002. Akuntansi Pemerintahan, Jakarta (ID): Salemba Empat.

Asfiansyah A. 2015. Strategi Implementasi Akuntansi Akrual Pada Pemerintah Daerah (Studi Kasus Pada Pemerintah Kota "S"). Jurnal NeO-Bis 9(1): 1-19.

Atan R. 2015. Accrual Accounting Change: Malaysian Public Sector Readiness. Journal of Management Research 7(2): 459-467. 
Bastani P, Abolhalaj M, Jelodar MH, Ramezanian M. 2012. Role of Accrual Accounting in Report Transparency and Accountability Promotion in Iranian Public Health Sector. Middle-East Journal of Scientific Research 12 (8): 1097-1101.

Baswir R. 2000. Akuntansi Pemerintahan Indonesia, Edisi Ketiga. Yogyakarta (ID): BPFE.

Craig JC, Grant RM. 1996. Manajemen Strategi Sumber-sumber Daya Perencanaan. Jakarta (ID): PT. Elex Media Koputindo.

Hoesada J. 2010. Accrual Budgeting dan Accrual Accounting Pada Pemerintah NKRI. Jurnal Akuntansi 14(1): 113-124

Ikatan Akuntan Indonesia. 2010. Pernyataan Standar Akuntansi Keuangan Pelaporan Entitas Nirlaba. Jakarta (ID): Dewan Standar Akuntansi Keuangan.

Langelo F, Saerang DPA, Alexander SW. 2015. Analisis Penerapan Standar Akuntansi Pemerintahan Berbasis Akrual Dalam Penyajian Laporan Keuangan Pada pemerintah Kota Bitung. Jurnal EMBA 3(1):1-8

Mahadi R, Noordin R, Mail R, Sariman K. 2014. Accrual Accounting in Malaysia: What We Should Learn from Others. Malaysian Journal of Business and Economics 1(2).

Mahat F, Ali NA. 2014. Human Perspective on Cash to Accrual Based Accounting System in Malaysia. Global Review of Accounting and Finance: 1-15.

Mahmudi. 2011. Akuntansi Sektor Publik. Yogyakarta (ID): UII Press.

Marrus. 2002. Manajemen Pelayanan Umum di Indonesia. Jakarta (ID): PT. Bumi Aksa

Mehrolhassani MA, Mahani AK, Emami M. 2015. Implementation Status of Accrual Accounting System in Health Sector. Global Journal of Health Science 7(1);24-34

Mulyadi. 2007. Sistem Terpadu Pengelolaan Kinerja Personal Berbasis Balanced Scorecard. Yograkarta (ID): Unit Penerbit dan Percetakan Sekolah Tinggi Ilmu Manajemen YKPN.

Mursyidi. 2009. Akuntansi Pemerintahan di Indonesia. Bandung (ID): PT. Refika Aditama.

Ofoegbu GN. 2014. New Public Management and Accrual Accounting Basis for Transparency and Accountability in the Nigerian Public Sector. IOSR Journal of Business and Management: 104-113.

Pemerintah Republik Indonesia. 2010. Peraturan Pemerintah Nomor 71 Tahun 2010 Tentang Standar Akuntansi Pemerintahan. Jakarta (ID): Sekretaris Negara.

Pemerintah Republik Indonesia. 2012. Undang-Undang Nomor 12 Tahun 2012 Tentang Pendidikan Tinggi. Jakarta (ID): Sekretariat Negara.

Pemerintah Republik Indonesia. 2013. Peraturan Pemerintah Nomor 66 Tahun 2013 Tentang Statuta Institut Pertanian Bogor. Jakarta (ID): Sekretaris Negara.

Petre CAB, Cosmina M. 2009. Arguments for introducing accrual based accounting in the public sector. MPRA Paper No. 18134.

Saaty TL. 1993. Pengambilan Keputusan bagi Para Pemimpin, Seri Manajemen No, 134, Proses Hirarki Analitik untuk Pengambilan Keputusan dalam Situasi yang Kompleks. Jakarta (ID): PT, Pustaka Binaman Pressindo.

Sugiyono. 2008. Metode Penelitian Bisnis. Alfabeta (ID): Bandung.

Sugiyono. 2010. Metode Penelitian Administrasi. Bandung (ID) : CV Alfabet.

Upping P, Oliver J. 2011. Accounting Change Model for the Public Sector: Adapting Luder's Model for Developing Countries. International Review of Business Research Papers: 364-380. 